\title{
A new infaunal species of the alpheid shrimp genus Salmoneus Holthuis, 1955 (Crustacea: Decapoda: Alpheidae) \\ and a new crustacean association from anoxic mangrove habitats in southern Vietnam
}

\author{
Новый инфаунный вид креветок-альфеид рода Salmoneus \\ Holthuis, 1955 (Crustacea: Decapoda: Alpheidae) и новая \\ ассоџиаџия ракообразных из бескислородных мангровых \\ местообитаний на юге Въетнама
}

\author{
Ivan N. Marin \\ Иван Н. Марин
}

\begin{abstract}
A.N. Severtsov Institute of Ecology and Evolution of RAS, Moscow 119071, Russia. E-mail: coralliodecapoda@mail.ru Joint Russian-Vietnamese Tropical Research and Technological Center, Hanoi, Vietnam.

Институт экологии и эволюции им. А.Н. Северцова РАН, Москва 119071, Россия.

Совместный Российско-Вьетнамский тропический научно-технологический центр, Ханой, Вьетнам
\end{abstract}

KEY WORDS: biodiversity, Crustacea, mangrove, communities, burrowing fauna, association, Vietnam, Indo-West Pacific.

КЛЮЧЕВЫЕ СЛОВА: биоразнообразие, Crustacea, мангры, сообщества, роющая фауна, ассоциации, Вьетнам, Индо-Вест Пацифика.

ABSTRACT. A new infaunal shrimp of the genus Salmoneus Holthuis, 1955 (Crustacea: Decapoda: Alpheidae) is described from the burrows of the mangrove-dwelling alpheid shrimps Alpheus cf. euphrosyne de Man, 1897, Alpheus aff. lobidens De Haan, 1849 and upogebiid mud shrimp Wolffogebia phuketensis (Sakai, 1982) in a deep mangrove swamps of the Can Gio Mangrove Biosphere Reserve, South Vietnam. Salmoneus spiridonovi sp.n. appears morphologically close to the eastern Atlantic $S$. erasimorum Dworschak, Anker et Abed-Navandi, 2000, S. caboverdensis Dworschak, Anker et Abed-Navandi, 2000, the western Atlantic S. degravei Anker, 2010, and the Indo-West Pacific S. seticheles Anker, 2003, S. brucei Komai, 2009, S. yoyo Anker, Firdaus et Pratama, 2014 and S. durisi Anker, 2019, which are characterized by both pereiopods I (chelipeds) being enlarged, subequal in size, but asymmetrical in the shape, clearly separating them from other species in the genus. Moreover, the new species is the first representative of the genus Salmoneus recorded as an infaunal associate of upogebiid burrows.

How to cite this paper: Marin I.N. 2021. A new infaunal species of the alpheid shrimp genus Salmoneus Holthuis, 1955 (Crustacea: Decapoda: Alpheidae) and a new crustacean association from anoxic mangrove habitats in southern Vietnam // Arthropoda Selecta. Vol.30. No.3. P.369-385. doi: 10.15298/arthsel. 30.3.10
РЕЗЮМЕ. Новый вид инфаунных креветок рода Salmoneus Holthuis, 1955 (Crustacea: Decapoda: Alpheidae) описан из нор альфеидных креветок Alpheus cf. euphrosyne de Man, 1897, Alpheus aff. lobidens De Haan, 1849 и upogebiid mud shrimp Wolffogebia phuketensis (Sakai, 1982), обитающих в глубоких мангровых болотах мангрового биосферного заповедника Канзе (Can Gio), Южный Вьетнам. Salmoneus spiridonovi sp.n. морфологически близок к восточно-атлантическому $S$. erasimorum Dworschak, Anker et Abed-Navandi, 2000, S. caboverdensis Dworschak, Anker et Abed-Navandi, 2000, западно-атлантическому S. degravei Anker, 2010 и индо-пацифических $S$. seticheles Anker, 2003, S. brucei Komai, 2009, S. yoyo Anker, Firdaus et Pratama, 2014 и S. durisi Anker, 2019, которые характеризуются увеличеными и субэквивалентными по размеру, но асимметричными хелипедами (переоподами I), что четко отделяет их от других видов рода. Более того, новый вид является первым представителем рода Salmoneus, зарегистрированным в качестве инфаунного партнера (симбионта) нор креветок-упогебиид.

\section{Introduction}

The Can Gio Mangrove Biosphere Reserve $\left(10^{\circ} 22^{\prime}-\right.$ $\left.10^{\circ} 40^{\prime} \mathrm{N}, 106^{\circ} 46^{\prime}-107^{\circ} 00^{\prime} \mathrm{E}\right)$, mainly forested by about 20-year-old monocultural forests of Rhizophora apicu- 
lata B1. (Rosacea: Rhizophoraceae), was declared a UNESCO Biosphere Reserve in 2000, although a significant part of the territory of this area is still used as agricultural land, in particular for shrimp farming. After the establishment of the national park, an active study on the biological diversity and structure of mangrove communities was started there [Van Xuân, 1992, 2001; Diele et al., 2013; Kuenzer, Vo, 2013; CostaBöddeker et al., 2016; Pham, 2017; Ashelby et al., 2018; David et al., 2018, 2019; Shih et al., 2019; Vinh et al., 2020; Marin, 2021]. Continued research on mangroves is critical, as they play a predominant role in tropical coastal areas around the world, providing a wide range of biological diversity, environmental and social services, such as protection from storms and coastal erosion [Moberg, Rönnbäck, 2003; Walters et al., 2008]. In addition, especially in Southeast Asia, mangroves are seriously threatened: about $20 \%$ of the total mangrove area has been lost since 1980 [FAO, 1993, 2007], while at least $35 \%$ of this area was lost between 1980 and 2000 worldwide [Valiela et al., 2001].

As in many other mangrove ecosystems of the IndoWest Pacific, deep areas of mangrove forests provide a source of accumulation of alluvial sediment, and are formed by dark gray or black marsh mangrove soils, which are characterized by low level of oxwgen and the presence of hydrogen sulfide, mostly because of the activity of anaerobic sulfur-reducing bacteria (e.g., Desuifovibrio sp.) [Ng, Sivasothi, 2002; Hossain, Nuruddin, 2016]. Such conditions are very difficult for various burrowing species to live in, so most of the species that inhabit mangrove swamps are habitat-specific, in contrast to the outer areas of mangrove forests, where bioturbation effect is sufficient.

A detailed study on the crustacean biodiversity in the central parts of the Can Gio Mangrove Biosphere Reserve in April 2020 revealed several specific infaunal species associated with larger burrowing animals. In the presented contribution, a new species of the genus Salmoneus Holthuis, 1955 (Crustacea: Decapoda: Alpheidae) from burrows of large burrowing crustaceans, which are also specific to anoxic mangrove swamps, is described as new to science.

\section{Material and methods}

Sampling was carried out within the scientific program of the Joint Russian-Vietnamese Tropical Research and Technological Center (Tropical Center) in the upper channel zone of the deep mangrove forests in the Can Gio Mangrove Biosphere Reserve near the Vietnam-Russian Climatic Research Station (CRS "Can Gio") (10²7'19.1"N 106 53' $32.9^{\prime \prime E}$ ) (Fig. 1) in March-April (dry season) 2020. The animals were collected from different burrows on the muddy substrate using a bait suction pump (yabby-pump). Some burrows of large burrowing and infaunal animals located above the water level and the adjacent areas were carefully excavated with a shovel, and then manually with hands. All collected animals were photographed alive using a Canon G16 digital camera and then fixed with $90 \%$ ethanol solu- tion. The drawings were made using lucida camera attached to Olympus SZX10 stereo microscope.

Carapace length (cl., in $\mathrm{mm}$ ), measured from the tip of the rostrum to the midpoint of the posterodorsal margin of the carapace, and total body length (tbl., in $\mathrm{mm}$ ), represented by the dorsal length from the tip of rostrum to the posterior margin of telson, are used as standard measurements. Although it is quite difficult to determine the sex of representatives of the genus Salmoneus as both sexes have appendix masculina on pleopods II, it is still possible to clearly habitually distinguish two groups in the collected individuals (see Fig. 2) - conditionally related to females ( + ), individuals with eggs/developed pleurae and relatively less developed pereopods I (chelipeds), and conditionally related to males $\left(\mathrm{O}^{7}\right)$, individuals always without eggs, less developed pleurae and relatively more developed pereopods I (chelipeds). Further, they will be mentioned in this way as o (female) or $\sigma^{7}$ (male), respectively, but it is worth mentioning that the real gender may be erroneous.

Barcoding segment of the cytochrome $\mathrm{c}$ oxidase subunit I (COI) mtDNA, used as one of the most informative gene markers for genetic studies at population and species level [Avise, 1993], was amplified with the help of the universal primers COIF (5'-CCAGCTGGAGGAGGAGAYCC-3') and H7188 (5'-CATTTAGGCCTAAGAAGTGTTG-3') [Kessing et al., 1989; Knowlton et al., 1993]. PCR products were performed on amplificator T100 (Bio-Rad, USA) under the following standard recommended conditions. The volume of $10 \mathrm{uL}$ of reaction mixture contained $1 \mathrm{uL}$ of total DNA, $2 \mathrm{uL}$ of 5xPCR mix (Dialat, Russia) and $1 \mathrm{uL}$ of each primer. The amplification products were separated by using gel electrophoresis of nucleic acids on a $1.5 \%$ agarose gel in $1 \times$ TBE, and then stained and visualized with $0.003 \% \mathrm{EtBr}$ using imaging UV software. DNA nucleotide sequences were determined using Genetic Analyzer ABI 3500 (Applied Biosystems, USA) and BigDye 3.1 (Applied Biosystems, USA) with direct and reverse primers. Aligned sequences of COI mtDNA gene marker, 658 base pairs in length, are deposited in GenBank (NCBI). No further phylogenetic analysis was performed, as only two sequences of the genus Salmoneus are currently present in genetic databases.

The type material is deposited in the collection of the Zoological Museum of Moscow State University, Moscow, Russia (ZMMU) and the Laboratory of Ecology and Evolution of Marine Invertebrates of A.N. Severtsov Institute of Ecology and Evolution of Russian Academy of Sciences, Moscow, Russia (LEMMI).

\section{Taxonomy}

Order Decapoda Latreille, 1802

Family Alpheidae Rafinesque, 1815

Genus Salmoneus Holthuis, 1955 Salmoneus spiridonovi sp.n. Figs 2-8.

HOLOTYPE $\mathrm{O}^{7}$ (non-ovigerous specimen), cl. $5.0 \mathrm{~mm}$, tl. 15.3 mm, ZMMU Ma-6185 - VIETNAM, Ho Chi Minh District, Can Gio Mangrove Biosphere Reserve, $10^{\circ} 27^{\prime} 30.7^{\prime \prime} \mathrm{N} 106^{\circ} 53^{\prime} 35.7^{\prime \prime} \mathrm{E}$, inside burrows of Alpheus cf. euphrosyne along the banks of canals deep in mangroves, yabby-pump sampling, coll. I. Marin \& S. Sinelnikov, 25.042020.

PARATYPES, $1 \mathrm{O}^{7}$ (non-ovigerous specimen), cl. $4.7 \mathrm{~mm}$, tl. $15.0 \mathrm{~mm}$, ZMMU Ma-6186 (dissected); 1 ovigerous + , cl. $5.3 \mathrm{~mm}$, tl. $16.5 \mathrm{~mm}$, ZMMU Ma-6187 - same locality as for holotype, inside burrows of Alpheus cf. euphrosyne and Alpheus aff. lo- 


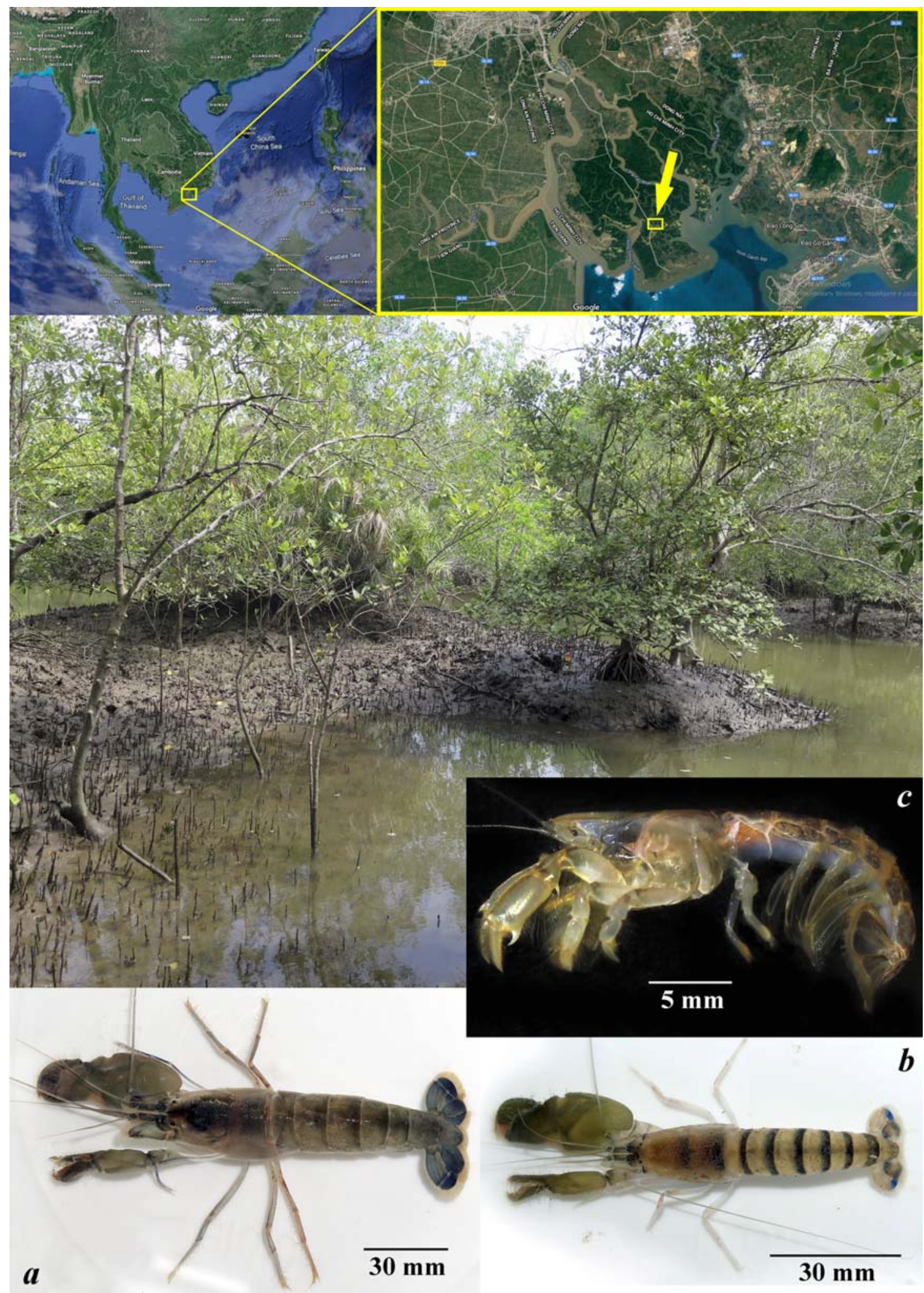

Fig. 1. The location of the Can Gio Mangrove Biosphere Reserve in South Vietnam (upper map) and typical biotopes in the locality, where Salmoneus spiridonovi sp.n. was collected (lower) with the other burrowing crustaceans (Alpheus cf. euphrosyne de Man, 1897 (a), Alpheus sp. aff. lobidens De Haan, 1849 (Alpheidae) (b) and mudshrimp Wolffogebia phuketensis K. Sakai, 1982 (Upogebiidae) (c)).

Рис. 1. Расположение мангрового биосферного заповедника Канзе в Южном Вьетнаме (верхняя карта) и типичные биотопы в местности, где был собран Salmoneus spiridonovi sp.n. (нижнее фото) соместно с другими роющими ракообразными (Alpheus cf. euphrosyne de Man, 1897 (a), Alpheus sp. aff. lobidens De Haan, 1849 (Alpheidae) (b) и креветками Wolffogebia phuketensis K. Sakai, 1982 (Upogebiidae) $(c))$. 
bidens, 17.04-2.05.2020; 1 ovigerous ${ }^{\circ}$, cl $5.2 \mathrm{~mm}$, tl $16.0 \mathrm{~mm}$ (LEMMI), ZMMU Ma-6188 — same locality as for holotype, inside manually excavated burrow of Wolffogebia $\mathrm{cf}$. phuketensis, coll. I. Marin \& S. Sinelnikov, 25.04.2020.

ADDITIONAL MATERIAL, 2 ovigerous +क; 2 non-ovigerous of; 6 non-ovigerous $\sigma^{7} \sigma^{7}$ (LEMMI) — same locality as for holotype, inside burrows of Alpheus cf. euphrosyne and Alpheus aff. lobidens, 17.04-2.05.2020.

DESCRIPTION. Small-sized (maximum cl. $5.3 \mathrm{~mm}, \mathrm{tl}$ $16.3 \mathrm{~mm}$ ) alpheid shrimp with subcylindrical body form (Figs 2, 8). Carapace covered with fine, erect setae dorsally (Figs 2, 3b, $d$ ). Rostrum well developed, flattened dorsoventrally, triangular in dorsal view, broad at base, reaching midlength of second article of antennular peduncle, directed forward, nearly straight; tip acute, dorsal surface non-carinate; ventral margin with distinct subapical tooth; lateral margins sharply edged (Fig. $3 a, b, d$ ); carapace anterior margin with well-developed, acute orbital teeth, directed somewhat mesially in dorsal view, anteriorly in lateral view (Fig. 3a, $b, d$ ); pterygostomial region broadly rounded; anterolateral suture present (Fig. 3b, d); cardiac notch deep (Fig. 2). Epistomial sclerite with low protuberance. Upper lip with crested median lobe.

Eyestalks (Fig. 3a, b, d,e) visible dorsally and exposed laterally, concealed by anterior part of carapace for about 1/ 3 , with dorsomesial distal tubercle; cornea (Fig. 3e) located at anterolateral part of eyestalk, darkly pigmented, somewhat reduced-

Pleon with pleurae I-IV broadly rounded to slightly angular, pleura $\mathrm{V}$ with posteroventral margin forming subacute angle (Fig. 2); pleura VI without articulated flap, posterior margin blunt, not acutely produced (Fig. $7 g$ ); preanal plate rounded and medially depressed.

Telson (Fig. 7h) moderately slender, subtrapezodal, tapering distally, about 2.5 times as long as proximal width; dorsal surface with two pairs of short stout spines at about 0.5 and 0.8 of telson length; posterior margin with deep Ushaped notch filled with 7-9 long plumose setae, and flanked by 3 pairs of long spines.

Antennular peduncle moderately stout (Fig. $3 f, g$ ); stylocerite (Fig. 3f) moderately slender, falling slightly short of distal margin of antennular article 2; ventromesial carina with small, anteriorly directed tooth (Fig. 3h); antennular article 2 about as long as wide, shorter than basal antennular article; outer flagellum subdivided almost at base, with 6-7 fused articles, and secondary ramus with 6-7 groups of aesthetascs.

Antenna (Fig. 3i) moderately robust; basicerite bearing sharp, triangular distoventral tooth; scaphocerite broad and ovoid in shape, about 1.5-1.7 times as long as wide, just reaching distal end of antennular peduncle, with straight lateral margin and broadly convex blade, distolateral tooth sharp, slightly overreaching distal margin of blade; carpocerite short, cylindrical, slightly overreaching mid-length of scaphocerite.

Mouthparts typical for genus. Mandible (Fig. 4a) incisor process armed with 5 or 6 teeth; molar process well developed; palp 2-articulated. Maxilla I (Fig. 4b) with distal endite broad, bearing spinules on distomesial margin; endopod bilobed, subterminal lobe bearing long spine, terminal lobe unarmed. Maxilla II (Fig. 4c) with distal endite broad, bilobed, edged with fine simple setae; proximal endite well developed, bilobed, edged with fine simple setae; scaphognathite well developed. Maxilliped I (Fig. 4d) with endite bilobed, distally with row of short fine setae; exopod well developed, with broad caridean lobe; endopod slender, un- segmented, with 2 long setae subdistally and several plumose setae along mesial margin; epipod broad. Maxilliped II (Fig. 4e) with well-developed exopod and ear-shaped epipod. Maxilliped III (Fig. 4f) slender, pediform; coxa (Fig. $4 g$ ) with rounded lateral plate, and strap-like epipod with terminal hook; antepenultimate article slightly flattened ventrolaterally; penultimate article less than 7 times as long as wide; ultimate article tapering distally, with numerous rows of short serrulate setae and long simple setae, tip (Fig. 4h) with sharp corneous point and 2 long spiniform setae subdistally; arthrobranch well-developed, multi-lamellate (Fig. $4 g)$.

Pereiopods I (chelipeds) usually subequal in length, asymmetrical in shape, carried flexed (Fig. 8); coxae each with strap-like epipod and setobranch consisting of 2 moderately long setae; bases as long as wide, unarmed. Major cheliped almost similar between males (Fig $5 a-c$ ) and females (Fig. $6 a, b)$; coxa as long as wide; ischium slightly flattened ventrolaterally, 3-3.5 times as long as wide, with small movable spine proximoventrally; merus about 6 times as long as maximal width, somewhat wider near mid-length, smooth, unarmed, ventrolateral surface distinctly depressed to accommodate flexed carpus and chela; carpus constricted proximally, cup-shaped, with three lobes distally; chela (Figs $5 b, 6 b)$ subcylindrical, rounded in cross-section; palm subequal to fingers in length, smooth, flexor margin with a dense row of fine setae extending inward onto pollex, extensor margin with some long fine setae subdistally; fingers (Figs $5 c, 6 b$ ) not gaping when closed, subequal in length, crossing distally, with evenly serrated cutting edges; cutting edges of both dactylus and pollex with 13-15 subtriangular teeth; dactylus with a dense row of long fine setae extending inward along its dorsal margin. Minor cheliped similar in proportion to major cheliped with slightly stouter chela, near similar between males (Fig. $5 d-f$ ) and females (Fig. $6 c-$ $e$ ); ischium slightly flattened ventrolaterally, about 4 times as long as wide, with small movable spine proximoventrally; merus 6-6.5 times as long as maximal width, somewhat wider near mid-length, smooth, ventrolateral surface depressed; carpus somewhat bent, cup-shaped, with three lobes distally; chela (Figs 5e, 6d) slightly compressed, oval in cross-section; palm about 1.5 times as long as dactylus, smooth, flexor margin with a dense row of long fine setae extending onto inward pollex, extensor margin also with row of long fine setae distodorsally; fingers (Figs $5 f, 6 e$ ) somewhat gaping when closed, crossing distally; dactylus longer than pollex, slightly twisted, strongly curved distally, its cutting edge armed with one proximal low tooth-like process and two distinct teeth, distal portion unarmed, hiatus-like, dorsal margin with a dense row of long fine setae directed inward along its dorsal margin; pollex less strongly curved compared to dactylus, its cutting edge armed with two large teeth intercalating with dactylar teeth, distal part significantly sloped, with 2 or 3 triangular teeth in males (Fig. $5 g$ ) and less stronger teeth in females (Fig. 6f).

Pereiopod II (Fig. 7a) slender. Coxa as long as wide, with strap-like epipod and setobranch consisting of 2 setae. Basis as long as wide, unarmed. Ischium unarmed, about 7 times as long as wide. Merus equal in length to ischium, unarmed. Carpus with 5 subarticles with ratio 4.5/1/1/1/1.5. Chela longer than distal-most carpal subarticle.

Pereiopod III (Fig. 7b) moderately slender. Coxa about 1.4 times as long as wide, with strap-like epipod and setobranch consisting of 2 setae. Basis as long as wide, unarmed. Ischium about 4 times as long as wide, with 2 mov- 

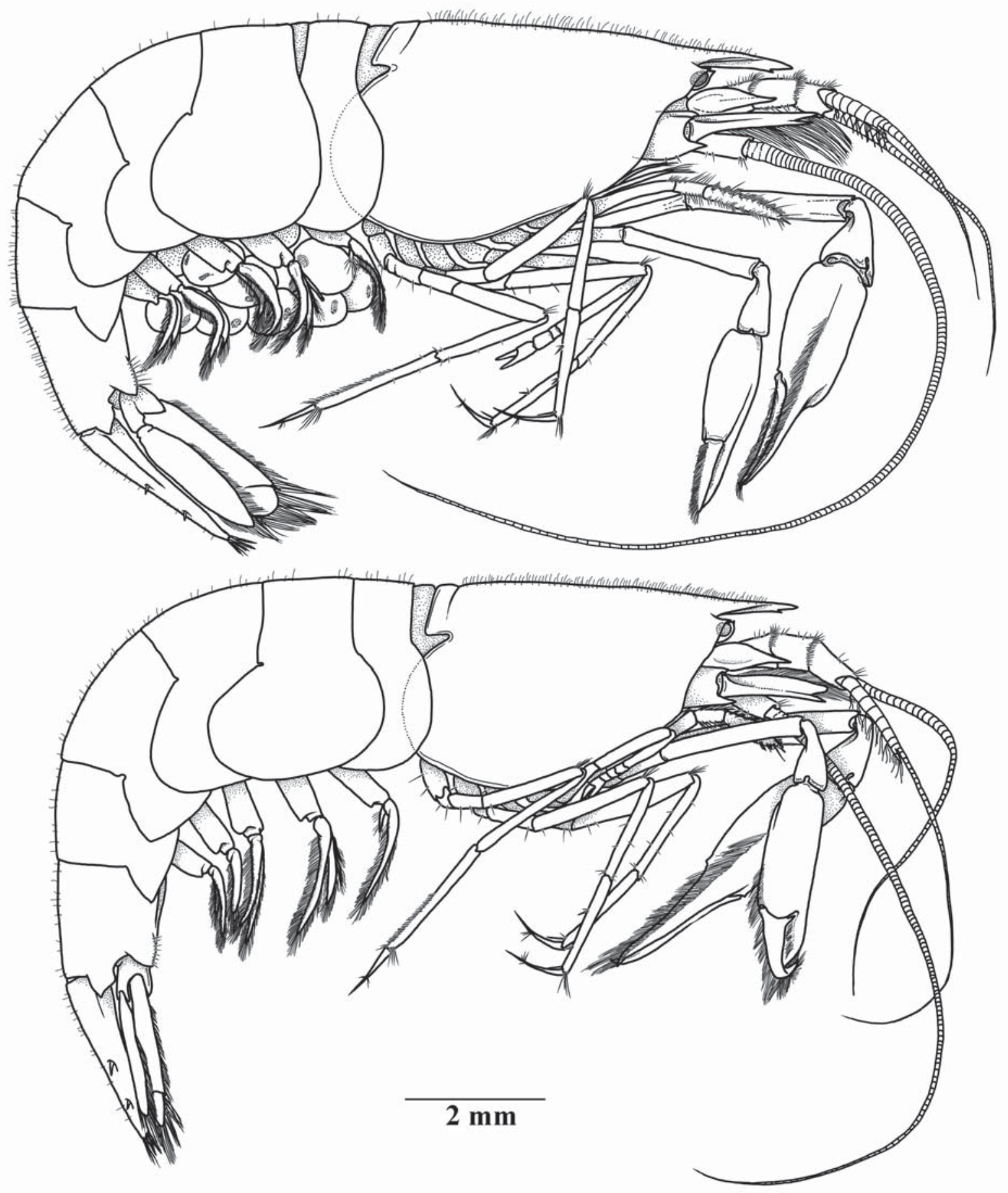

Fig. 2. Salmoneus spiridonovi sp.n., habitus in lateral view. Upper, paratype, ZMMU Ma-6187, conditionally ovigerous female,,+ lower, holotype, ZMMU Ma-6185, conditionally male, $\sigma^{7}$ (non-ovigerous specimen).

Рис. 2. Salmoneus spiridonovi sp.n., общий вид, вид сбоку. Верхний, паратип, ZMMU Ма-6187, условно половозрелая самка с яйцами, о; нижний, голотип, ZMMU Ма-6185, условно самец, О7 (не-яйценосная особь).

able spines on ventrolateral surface. Merus $7-7.5$ times as long as wide, unarmed. Carpus almost subequal in length to merus, noticeably slender, about $10-11$ times as long as wide, with small spiniform setae distoventrally. Propodus subequal in length to carpus, about 10 times as long as wide, with 2 widely spaced spiniform setae on flexor margin, in addition to long spiniform setae at flexor distal margin, which is about $1 / 3$ of the length of dactylus; dactylus (Fig. $7 c$ ) about half-length of propodus, slender, gently curving distally, terminating in sharp tip.

Pereiopod IV (Fig. 7d) almost similar but slightly robust than pereiopod III; coxa about 1.5 times as long as wide, 


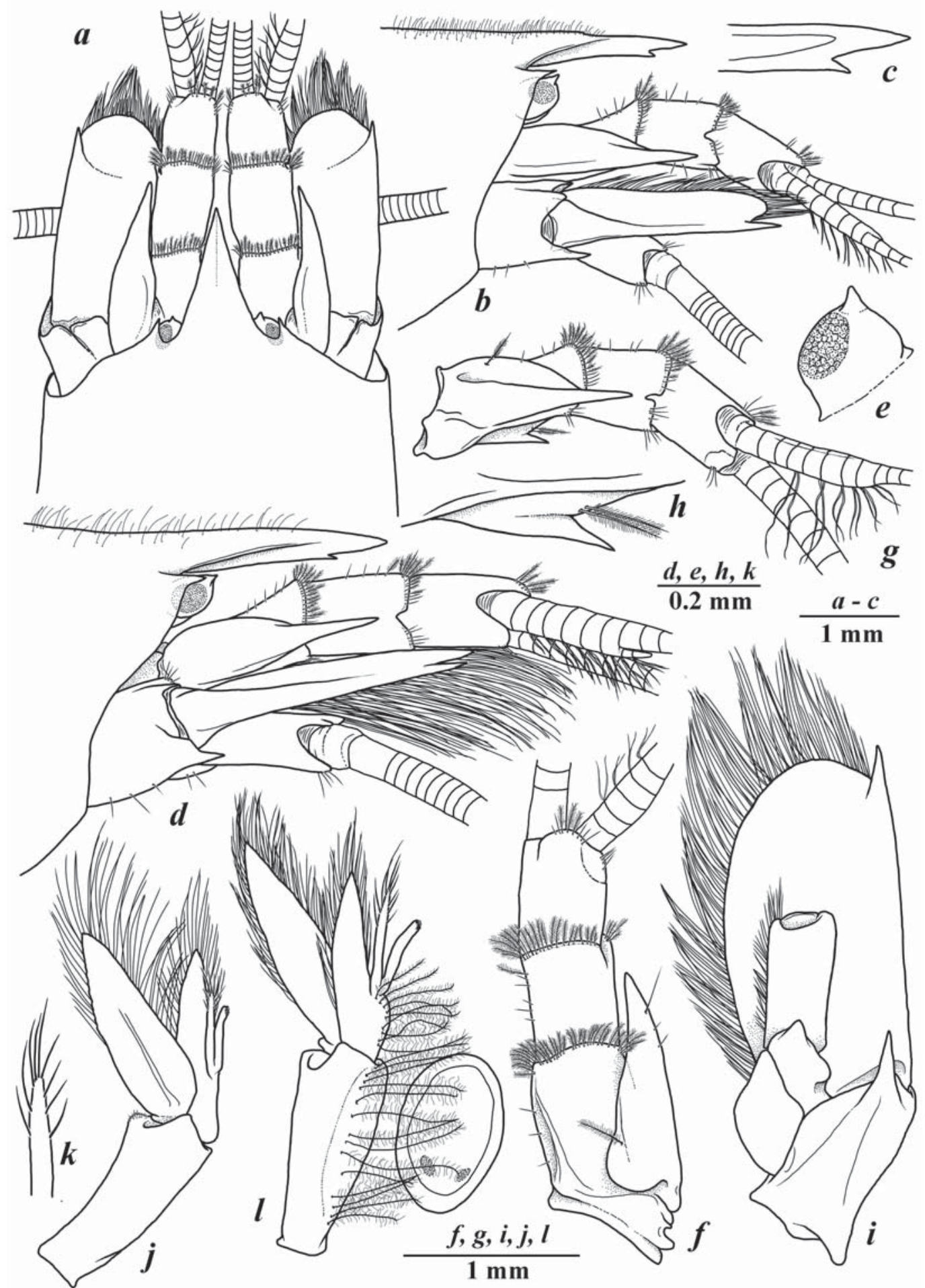

Fig. 3. Salmoneus spiridonovi sp.n., holotype, $\sigma^{7}$ (non-ovigerous specimen) (ZMMU Ma-6186) $(a-c)$, paratype $\sigma^{7}$ (non-ovigerous specimen) (LEMMI) $(e-k)$, paratype, ovigerous + (LEMMI) $(d, l): a$ - rostrum, anterior part of carapace and cephalic appendages, dorsal view; $b, d$ - rostrum and anterior part of carapace, lateral view; $c$ - tip of rostrum, lateral view; $e$ - eye, dorsal view; $f, g-$ right antennule, flagella partially omitted; $h$ - ventromesial tooth of basal article of right antennular peduncle; $i$ - left antenna, ventral view; $j$, $l$ - left pleopod II, dorsal view; $k$ - tip of appendix masculina, dorsal view.

Рис. 3. Salmoneus spiridonovi sp.n., голотип, О7 (не-яйценосная особь) (ZMMU Ma-6186) (a-c), паратип, $0^{7}$ (LEMMI) $(e-k)$, паратип, + с яйцами (LEMMI) $(d, l): a-$ рострум, передняя часть карапакса и головные придатки, вид сверху; $b, d-$ рострум и передняя часть карапакса, вид сбоку; $c$ - кончик рострума, вид сбоку; $e-$ глаз, вид сверху; $f, g-$ правая антенна, жгутики частично обрезаны; $h$ - вентромезиальный зубец базального членика правого антеннального стебелька; $i$ - левая антенна, вид снизу; $j, l$ - левый плеопод II, вид сверху; $k$ - кончик appendix masculina, вид сверху. 


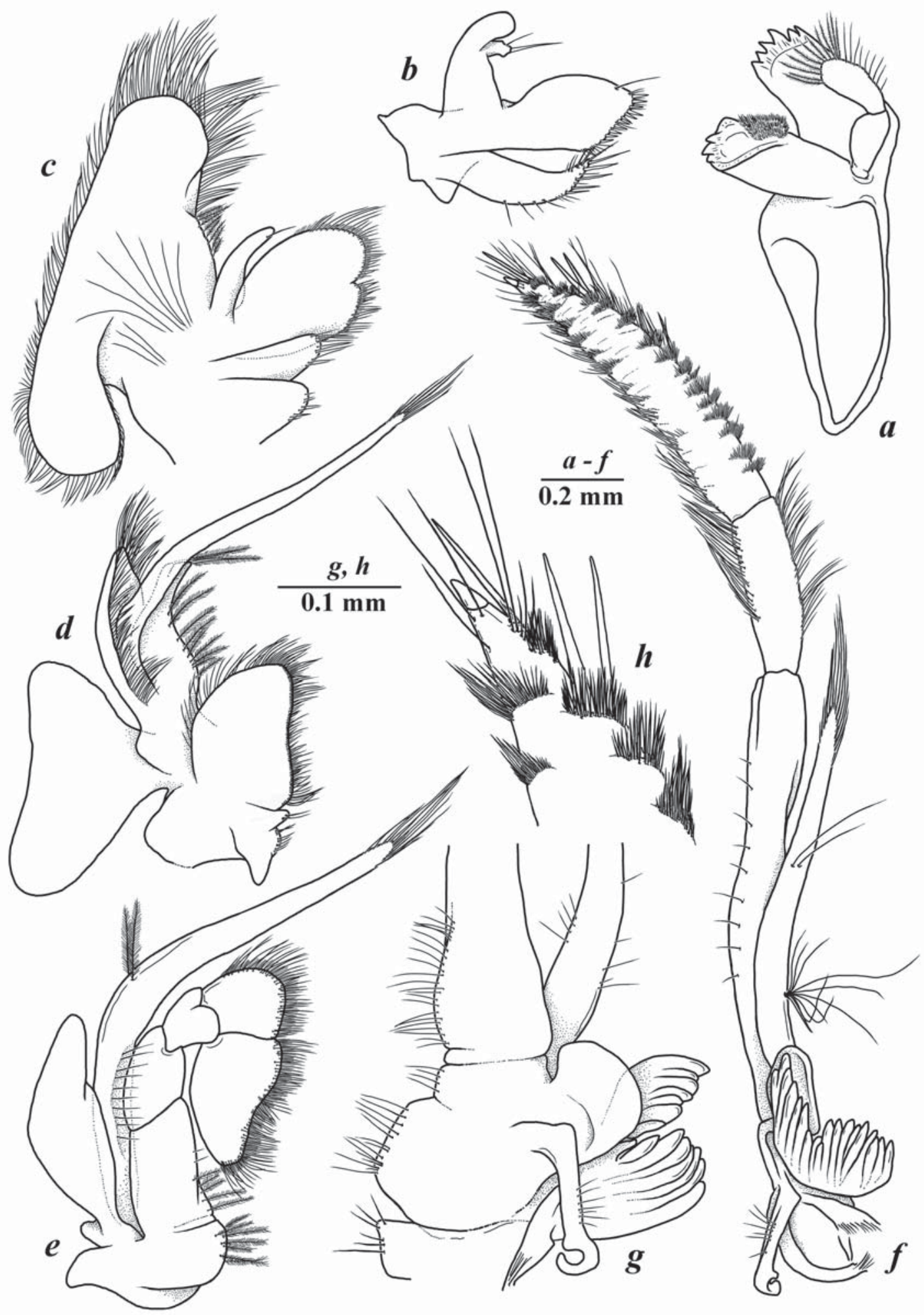

Fig. 4. Salmoneus spiridonovi sp.n., paratype, $\sigma^{7}$ (non-ovigerous specimen) (ZMMU Ma-6186): $a$ - right mandible, internal view; $b-$ left maxillula, outer view; $c$ - left maxilla, outer view; $d$ - left maxilliped I, outer view; $e$ - left maxilliped II, outer view; $f$ - left maxilliped III, lateral view; $g$ - coxa and basal part of antepenultimate article of left maxilliped III, ventral view; $h$ - tip of ultimate article of maxilliped III, lateral view.

Pис. 4. Salmoneus spiridonovi sp.n., паратип, О’ (не-яйценосная особь) (ZMMU Ma-6186): $a$ - правая мандибула, вид изнутри; $b$ - левая максиллула, вид снаружи; $c$ - левая максилла, вид снаружи; $d-$ левая максиллипеда I, вид снаружи; $e$ - левая максиллипеда II, вид снаружи; $f$ - левая максиллипеда III, вид сбоку; $g$ - кокса и базальная часть предпоследнего членика левой максиллипеды III, вентральный вид; $h$ - кончик дистального членика максиллипеды III, вид сбоку. 


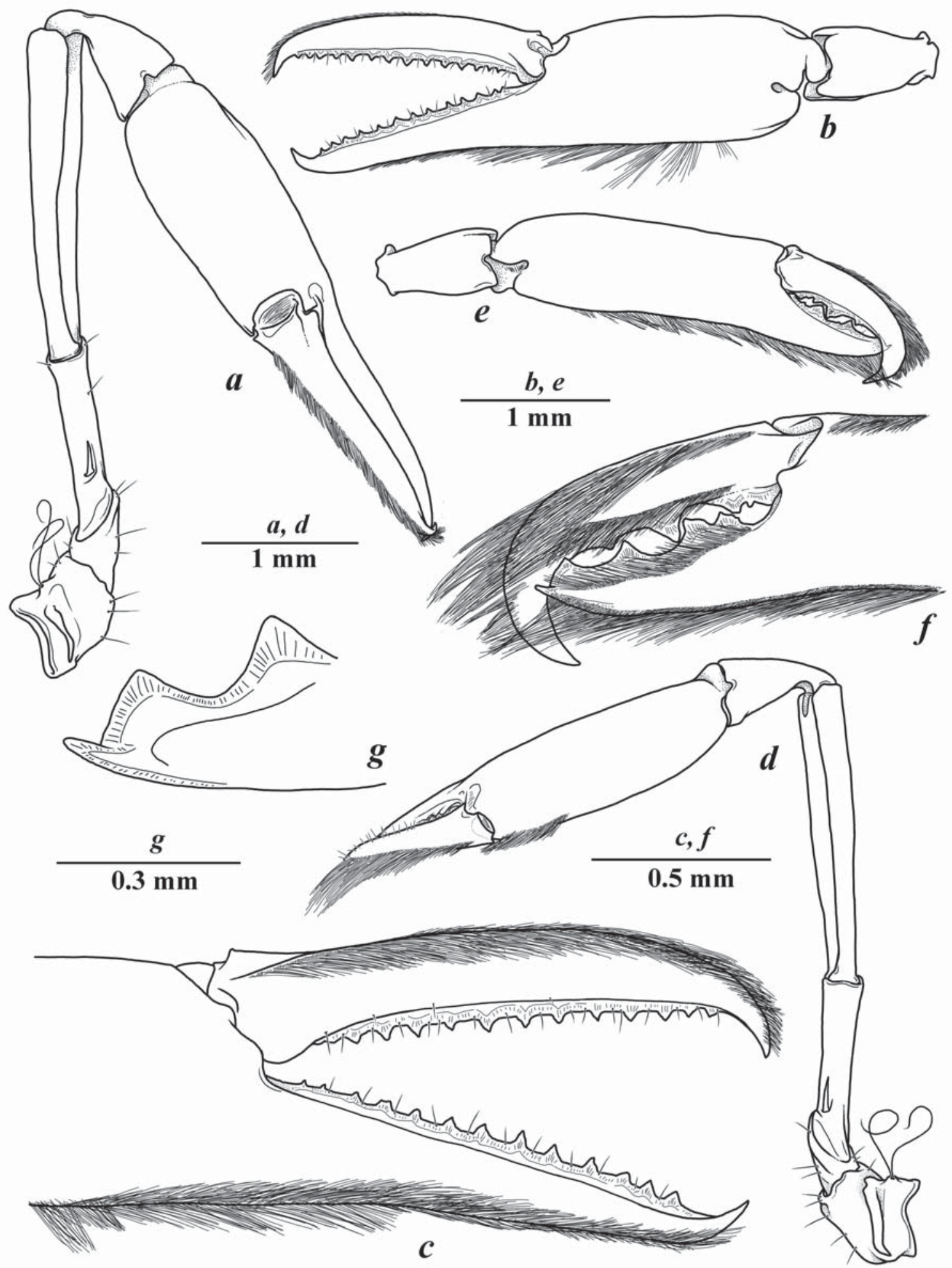

Fig. 5. Salmoneus spiridonovi sp.n., paratype, $\mathrm{O}^{7}$ (non-ovigerous specimen) (ZMMU Ma-6186): $a-$ major (right) pereiopod I (cheliped), lateral view; $b$ - same, carpus and chela, extensor view; $c$ - fingers of major pereiopod I, internal view; $d$ - minor (left) pereiopod I (cheliped), lateral view; $e$ - same, carpus and chela, extensor view; $f$ - fingers of minor pereiopod I, flexor view; $g$ - distal part of polex (fixed finger) of minor pereiopod I, flexor view.

Рис. 5. Salmoneus spiridonovi sp.n., паратип, О7 (не-яйценосная особь) (ZMMU Ma-6186): $a$ - большая (правая) переопода I (хелипеда), вид сбоку; $b-$ тот же, карпус и клешня, вид изнутри; $c$ - пальцы большой переоподы I, вид изнутри; $d-$ малая (левая) переопода I (хелипеда), вид сбоку; $e$ - тот же, карпус и клешня, вид изнутри; $f$ - пальцы малой переоподы I, вид изнутри; $g$ - дистальная часть полекса (неподвижного пальца) малой переоподы I, вид изнутри. 


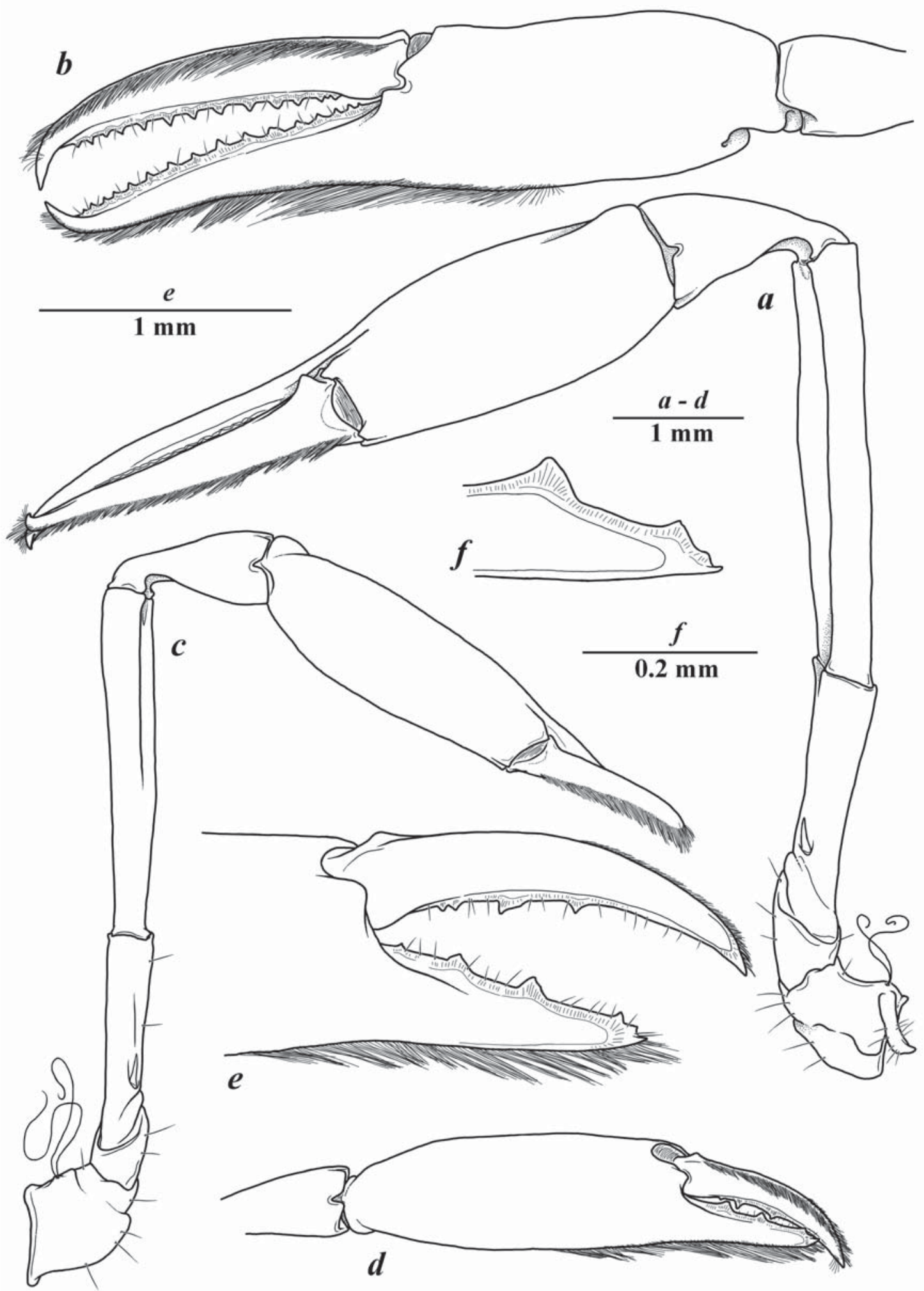

Fig. 6. Salmoneus spiridonovi sp.n., paratype, ovigerous 9 (LEMMI): $a$ - major (left) pereiopod I (cheliped), lateral view; $b-$ same, carpus and chela, internal view; $c$ - minor (right) pereiopod I (cheliped), lateral view; $d$ - same, carpus and chela, internal view; $e-$ fingers of major pereiopod I, internal view; $f$ - distal margin of polex (fixed finger) of minor pereiopod I, internal view.

Рис. 6. Salmoneus spiridonovi sp.n., паратип, яйценосная ㅇ (LEMMI): $a$ - большая (левая) переопода I (хелипеда), вид сбоку; $b-$ то же, карпус и клешня, вид сбоку; $c$ - малая (правая) переоподя I (хелипеда), вид сбоку; $d$ - то же, карпус и клешня, вид изнутри; $e$ — пальцы большой перейоподы I, вид изнутри; $f$ - дистальный край полекса (неподвижного пальца) малой переоподы I, вид изнутри. 


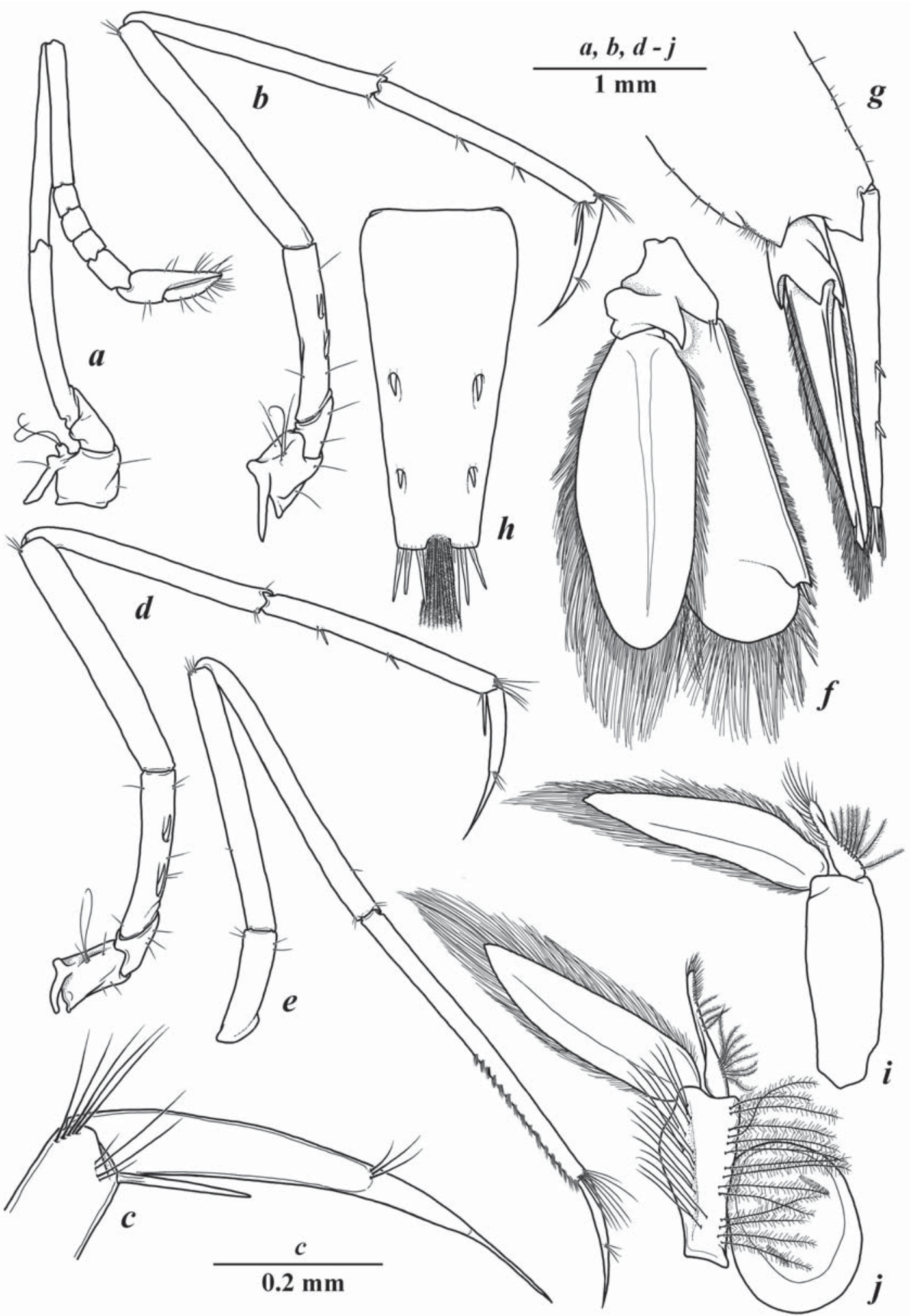

Fig. 7. Salmoneus spiridonovi sp.n., paratype, $\sigma^{7}$ (non-ovigerous specimen) (ZMMU Ma-6186) (a-i) and paratype $\odot$ (LEMMI) (j): $a-$ pereiopod II, outer view; $b$ - pereiopod III, lateral view; $c$ - dactylus of pereiopod III, lateral view; $d$ - pereiopod IV, lateral view; $e-$ pereiopod $\mathrm{V}$, lateral view; $f$ - uropods, internal view; $g$ - telson and uropods, lateral view; $h$ - telson, dorsal view; $i, j$ - left pleopod I, dorsal view.

Рис. 7. Salmoneus spiridonovi sp.n., паратип, О7 (не-яйценосная особь) (ZMMU Ma-6186) (a-i) и паратип + (ZMMU Ma-6186) (j): $a$ - переопод II, вид снаружи; $b$ - переопод III, вид сбоку; $c$ — дактилус переопод III, вид сбоку; $d$ - переопод IV, вид сбоку; $e$ - переопод $\mathrm{V}$, вид сбоку; $f$ - уроподы, вид изнутри; $g$ - тельсон и уроподы, вид сбоку; $h$ - тельсон, вид сверху; $i, j$ - левый плеопод I, вид сверху. 
with strap-like epipod and 2 setobranchs; basis as long as wide, unarmed; ischium about 4 times as long as wide, with 2 movable spines proximoventrally; merus about 6-7 times as long as wide, unarmed; carpus almost subequal to merus, noticeably slender, about 9-10 times as long as wide, with small spiniform setae distoventrally; propodus noticeably subequal to carpus, about 9 times as long as wide, with 2 widely spaced spiniform setae on ventral margin, in addition to long spiniform setae near dactylar base, which is about 1/ 3 of the length of dactylus; dactylus about half-length of propodus, moderately slender, simple, smoothly curving distally, with sharp tip.

Pereiopod V (Fig. 7e) more slender than pereiopods IIIIV; coxa 1.5 times as long as wide, unarmed; basis as long as wide, unarmed; ischium about 2.5 times as long as wide, unarmed; merus about 7 times as long as wide, unarmed; carpus noticeably more slender and slightly longer than merus, about 10 times as long as wide, shorter than propodus, unarmed; propodus long, slender, about 13-14 times as long as wide, with two dozens of serrulate setae forming moderate cleaning brush on distal ventrolateral surface, without spiniform setae; dactylus about 0.3 times length of propodus, distally curved, otherwise similar to dactyli of pereiopods III-IV.

Pleopods similar in males and females. Pleopod I (Fig. $7 i, j$ ) with appendix interna, furnished with simple setae distally and subdistally, and plumose setae along the mesial margin. Pleopod II (Fig. 3j, 1) with appendix masculina slightly shorter than appendix interna, appendix masculina furnished with 7-8 stiff setae on apex and subapical area (Fig. 3k).

Uropod (Fig. 7f, $g$ ) with protopod ending in sharp curved posterolateral tooth and median spine on posterodorsal margin just lateral to the base of the endopod. Exopod broadly ovoid, with small distolateral tooth and well-developed distolateral spine; diaeresis sinuous. Endopod as long as exopod, ovoid, unarmed.

Gill-exopod formula typical for genus, consisting of 1 arthrobranch above base of maxilliped III, 1 pleurobranch on each thoracomeres IV-VIII, corresponding to pereiopods $\mathrm{I}-\mathrm{V}$, epipods on maxillipeds $\mathrm{I}-\mathrm{III}$ and pereiopods $\mathrm{I}-\mathrm{IV}$, exopods on maxillipeds I-III and setobranch on pereopods I-V, corresponding to epipod on maxilliped III and pereopods I-IV.

COLOURATION IN LIFE. Body and appendages semitranslucent-whitish, dorsal surface of basal segments of antennules and antennae, carapace, pleon and telson densely covered with small red chromatophores; chelipeds, ambulatory pereiopod and uropods semitranslucent-whitish; eyes cornea red; eggs yellow (Fig. 8).

GENBANK ACCESSION NUMBERS. MZ575659575662

ETYMOLOGY. The new species is named in honour of the Russian carcinologist Dr. Vassily Albertovich Spiridonov (7.04.1957-17.12.2020), who, amongst other lines of study, worked on mangrove crustaceans in the Can Gio Mangrove Biosphere Reserve of South Vietnam [Chertoprud et al., 2012].

TAXONOMIC REMARKS. Salmoneus spiridonovi sp.n. morphologically similar to the eastern Atlantic $S$. erasimorum Dworschak, Anker et Abed-Navandi, 2000, S. caboverdensis Dworschak, Anker et Abed-Navandi, 2000, the western Atlantic $S$. degravei Anker, 2010, and the Indo-West Pacific S. seticheles Anker, 2003, S. brucei Komai, 2009, S. yoyo Anker, Firdaus et Pratama, 2014 and $S$. durisi Anker,
2019 [Dworschak et al., 2000; Anker, 2003, 2010, 2019; Komai, 2009; Anker et al., 2014]. All of these species are characterized by both pereiopods I (chelipeds) being enlarged, subequal in size, but asymmetrical in the shape, clearly separating them from other species in the genus (except some species from the "Salmoneus jarli" species group (see below)). However, the monophyly of this group is not phylogenetically tested and proven [Anker, 2019]. The monotypic genus Deioneus Dworschak, Anker et AbedNavandi, 2000 is morphologically close to those species of Salmoneus [Dworschak et al., 2000].

In most of diagnostic features, the new species is similar to the Indo-Pacific Salmoneus seticheles and S. durisi in the presence of a distoventral tooth on the rostrum, the general shape of the pereiopods I and the presence of rows of long fine setae on the flexor and extensor margins of the chelae of both pereiopods I.

From Salmoneus seticheles (see Anker [2003]), morphologically the most closely related species, the new species can be separated by 1) rostrum triangular in dorsal view, with well-developed lateral carina, reaching the mid-length of antennular article 2, with more developed distoventral tooth on rostrum; 2) ischium of both pereiopods I (chelipeds) armed with well-marked strong tooth; 3 ) the presence of dense row of long fine setae directed inward along dorsal margin of dactylus and ventral margin of polex and palm in both major and minor pereiopods I (vs. just row of long simple setae in S. seticheles [Anker, 2003: Figs 3B, 4]); 4) significantly sloped distal part of polex both in males and females (vs. "normal" sharp distal margin of polex in $S$. seticheles [Anker, 2003: Fig. 4B]); and 5) shorter distoventral spines on propodus of ambulatory pereiopods, especially pereiopod III, which are about $1 / 3$ of the length of dactylus (vs. about $1 / 5$ of the length of dactylus in $S$. seticheles [Anker, 2003: Fig. 3E]). Moreover, the holotype of S. seticheles [Anker, 2003] and the specimen from Singapore [Anker, De Grave, 2016] possess very asymmetrical and different in size pereiopods I, while all collected specimens of the new species, both non-ovigerous and ovigerous, have subequal pereiopods I.

From Salmoneus durisi, the new species can be separated by 1) relatively longer rostrum with well-developed distoventral tooth (vs. relatively shorter, without distoventral tooth in $S$. durisi [Anker, 2019: Fig. 1a, b, j]; 2) relatively slender telson, about 2.5 times as long as proximal width, in S. spiridonovi sp.n. (vs. about 2 times in $S$. durisi) [Anker, 2019: Fig. 1d]; 3) ischium of both pereiopods I (chelipeds) armed with well-marked movable spine; 4) the presence of dense and wide row of long fine setae along distoventral margin of palm, dorsal margin of dactylus and distal margin of polex in both major and minor pereiopods I in S. spiridonivi sp.n. (Figs 5,6) (vs. one row of sparse long simple setae in S. durisi [Anker, 2019: Fig. 3]); 4) oblique distal part of polex both in males and females (see Figs $5 g, 6 f$ ) (vs. "normal", pointed and elongated, distal part of polex in $S$. durisi [Anker, 2019: Fig. 3g]); and 5) different living coloration: carapace and pleon with deep red chromatophores in S. spiridonovi sp.n. (Fig. 8) (vs. entirely translucent whitish body in S. durisi [Anker, 2019: Fig. 4]).

The reduced cornea of the eyes easily separates the new species from Salmoneus yoyo and S. brucei. Moreover, these species can be further separated from the new species by the absence of a distoventral tooth on the rostrum and the morphology of chelipeds: $S$. yoyo has a number of blunt tubercles on the ventromesial margin of the merus and the propo- 

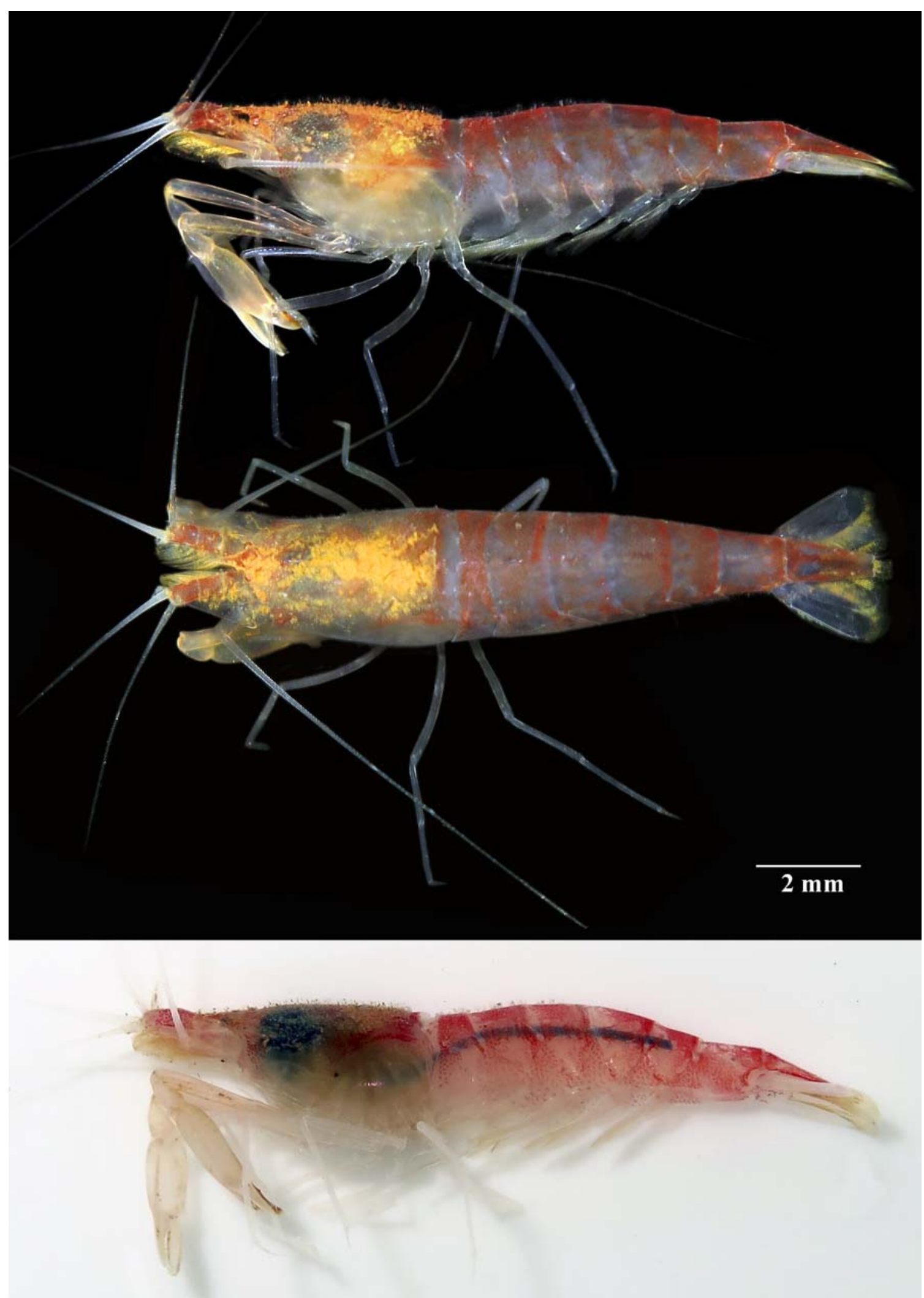

Fig. 8. Salmoneus spiridonovi sp.n., habitus of $\sigma^{7}$ (non-ovigerous specimen), showing living coloration. The yellow color on the carapace and antennae is due to particles derived from mangrove mud.

Рис. 8. Salmoneus spiridonovi sp.n., общий вид О7 (не-яйценосной особи), прижизненная окраска. Желтые частицы на карапаксе и антеннах представляют собой частицы мангровой грязи. 
dus of the pereiopod I (chelipeds), and lacks a row of fine setae along margins of the palm and dactylus [Anker et al., 2014: Fig. 2]; the beveled shape of the distal margin of polex in S. yoyo [Anker et al., 2014: Fig. 2F, G, H] is very similar to the new species. At the same time, $S$. brucei is rather distinctive in lacking supraorbital spines on the carapace and more robust pereiopods I (chelipeds), in particular, the meri, compared with the new species [Komai, 2009: Fig. 4; Anker, 2019: Fig. 5].

The eastern Atlantic S. erasimorum, S. caboverdensis, and the western Atlantic $S$. degravei Anker, 2010, which also have subequal pereiopods I (chelipeds), are easily distinguished from the new species by the unarmed ischia of both pereiopods 1 and the shape of their fingers, with very slender pincer-like fingers of the major cheliped and the stouter, subequal fingers of the minor chelipeds [Anker, 2010; Dworschak et al., 2000].

Three more species from the tropical western Pacific, namely Salmoneus komaii Anker, 2011, S. paulay Anker, 2011 and S. poupini, presently referred to the "S. jarli" species group [Anker, 2011], also have more or less similar pereiopods I, but differ from the new species in numerous features, including absence of the rostral teeth, better developed cornea of the eye, a different shape of fingers of the pereiopods I, the presence of 2 spines on the ischium of the pereiopod II and of 3 spines on the ischium of the pereiopod III and a translucent whitish body coloration [Anker, 2011].

HABITAT AND ECOLOGY. Sampling using a yabbypump allowed to obtain adult individuals of Salmoneus spiridonovi sp.n. from the burrows of two species of the alpheid shrimp genus Alpheus, the only species of the genus inhabiting mangrove swamps of the Can Gio mangrove forests Alpheus cf. euphrosyne de Man, 1897 and Alpheus aff. lobidens De Haan, 1849 (Fig. 1) (both are from species complexes [e.g., Cunha et al., 2020])) One adult ovigerous

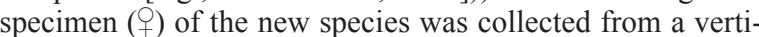
cal burrow (with a total length of up to 10-15 cm) of the upogebiid mud shrimp Wolffogebia cf. phuketensis Sakai, 1982 (Fig. 1c) during a manual burrow excavation together with the host. All individuals of Salmoneus spiridonovi sp.n. were collected individually per the host's burrow, sometimes with a single unidentified goby fish. Other burrowing and burrow-associated animals found in the same area during yabby-pump sampling were the mangrove stomatopod Clorida rotundicauda (Miers, 1880) (Stomatopoda: Squillidae), numerous burrowing sesarmid crabs (Decapoda: Sesarmidae), Metaplax spp. (Decapoda: Varunidae) and Uca spp. (Decapoda: Ocypodidae), Wolffogebia spp. (Decapoda: Upogebiidae), mud amphipods of the genus Victoriopisa Karaman et Barnard, 1979 (Amphipoda: Eriopisidae), different gobies, and the recently described alpheid shrimps Potamalpheops kisi Marin, 2021 (Decapoda: Alpheidae) [Marin, 2021]. All of them are specific to this biotope, representing a stable community characteristic of deep mangrove swamps, wetland pools and tidal creeks in the C?n Gi? Mangrove Biosphere Reserve, and have not been found on intertidal mudflats or the mangrove estuary.

DISTRIBUTION. Presently known only from the Can Gio Mangrove Biosphere Reserve, South Vietnam.

\section{Discussion}

The genus Salmoneus Holthuis, 1955 currently contains 50 species worldwide [De Grave, Fransen, 2011;
Anker et al., 2020; De Grave et al., 2020; Komai et al., 2021]. Most of the known species of the genus are freeliving, inhabiting crevices among coral rubbles, under rocks and boulders in tropical to temperate regions of all oceans [Anker, Marin, 2006; Anker, 2011; Komai, Anker, 2012; Anker, Lazarus, 2015; Komai et al., 2015; Ïuriš, Horká, 2016; Anker et al., 2015, 2020]. Some species are, however, known as infaunal symbionts of various burrowing marine invertebrates, such as echiuran worms [Anker et al., 2020; De Grave et al., 2020], larger burrowing alpheid shrimps of the genus Alpheus (Decapoda: Caridea: Alpheidae), as well as axiidean ghost shrimps of the family Callianassidae and Callichiridae (Decapoda: Axiidea) [Dworschak et al., 2000; De Grave, 2004; Anker, Marin, 2006; Komai, 2009; Anker, 2010] (Table 1). Several more described species also appear to be infaunal, but their hosts remain unknown [Felder, Manning, 1986; Anker et al., 2014; Komai el., 2021].

The habitat conditions of burrowing animals at the collection site in the Can Gio Mangrove Biosphere Reserve (see Fig. 1) are very difficult due to the anoxic fetid deep mud of alluvial origin with a high content of hydrogen sulfide beneath the surface (see above). The burrowing fauna here should be tolerant to low level of oxygen (hypoxia). It is very specific, and very likely endemic, and is represented here by the most prominent mudskippers and amphibious crabs, as well as a very limited number of other large burrowing crustaceans (see above). Amphibious caridean shrimps, such as Merguia spp. (Merguiidae) and Potamalpheops spp. (Alpheidae) are also characteristic for such deep mangrove swamp conditions [Gillikin et al., 2001; Marin, 2021]. The new species was mostly obtained from the burrows of large alpheid shrimps of the genus Alpheus, while the ovigerous female collected from the burrow of $W$. cf. phuketensis could be an accidental association. Actually, mud shrimps of the genus Wolffogebia are one of the few numerous burrowing crustaceans in the area, whereas $W$. phuketensis is known as a specialized deep mangrove swamp dwelling species, digging tunnels/burrows in or near mounds excavated by mud lobsters of Thalassina spp. (Decapoda: Gebiidea: Thalassinidae) in the upper littoral zone of such mangrove swamps [Ng, Kang, 1988]. The reduced cornea of the eyes of the Salmoneus appears to be linked to permanent cryptogenic habitats inside deep burrows of larger burrowing host as well as cloudy waters of mangrove communities.

Among the species of the genus Salmoneus, only Salmoneus carvachoi Anker, 2007 is known as infaunal associate of the western Atlantic gebiid ghost shrimps Axianassa australis Rodrigues et Shimizu, 1992 (Decapoda: Gebiidea: Axianassidae) [Anker, 2007; Oliveira et al., 2015] (Table 1). Thus, the present new species is the first representative of the genus Salmoneus known as infaunal associate of Wolffogebia and mud shrimps of the family Upogebiidae (Decapoda: Gebiidea), while Salmoneus became the sixth genus 
Table 1. Known infaunal crustacean associations of the genera Salmoneus and Deioneus.

Таблица 1. Известные ассоциации инфаунных креветок родов Salmoneus и Deioneus.

\begin{tabular}{|c|c|c|}
\hline Associated species & Host & Reference \\
\hline \multicolumn{3}{|c|}{ Alpheus spp. (Caridea: Alpheidae) } \\
\hline $\begin{array}{l}\text { Salmoneus alpheophilus Anker et } \\
\text { Marin, } 2006\end{array}$ & $\begin{array}{l}\text { in burrow of large goby-associated Alpheus } \\
\text { sp. }\end{array}$ & Anker, Marin, 2006 \\
\hline $\begin{array}{l}\text { Salmoneus carvachoi Anker, } \\
2007\end{array}$ & $\begin{array}{l}\text { in burrow of Alpheus estuariensis } \\
\text { Christoffersen, 1984, Alpheus chacei } \\
\text { Carvacho, } 1979\end{array}$ & $\begin{array}{c}\text { Anker, 2007; Oliveira et } \\
\text { al., } 2015\end{array}$ \\
\hline $\begin{array}{l}\text { Salmoneus colinorum De Grave, } \\
2004\end{array}$ & $\begin{array}{l}\text { larger snapping shrimps of Alpheus } \\
\text { malabaricus (Fabricius, 1775) species } \\
\text { complex }\end{array}$ & $\begin{array}{l}\text { De Grave, 2004; Anker } \\
\text { et al., 2015; Anker, } \\
2019\end{array}$ \\
\hline $\begin{array}{l}\text { Salmoneus rostratus Barnard, } \\
1962\end{array}$ & $\begin{array}{l}\text { in burrow of large goby-associated Alpheus } \\
\text { sp. }\end{array}$ & $\begin{array}{l}\text { Anker, 2003; Anker, } \\
\text { Marin, 2006; De Grave, } \\
\text { Wilkins, } 1997 . \\
\end{array}$ \\
\hline \multicolumn{3}{|c|}{ Ghost shrimps of the family Callianassidae (Axiidea) } \\
\hline Salmoneus brucei Komai, 2009 & $\begin{array}{l}\text { callianassid ghost shrimps Lepidophthalmus } \\
\text { tridentatus (von Martens, 1868) and L. cf. } \\
\text { rosae (Nobili, 1904) }\end{array}$ & $\begin{array}{l}\text { Komai, 2009; Anker, } \\
2019\end{array}$ \\
\hline $\begin{array}{l}\text { Salmoneus erasimorum } \\
\text { Dworschak, Anker et Abed- } \\
\text { Navandi, } 2000\end{array}$ & Gilvossius tyrrhena (Petagna, 1792) & Dworschak et al., 2000 \\
\hline \multicolumn{3}{|c|}{ Ghost shrimps of the family Callichiridae (Axiidea) } \\
\hline $\begin{array}{l}\text { Salmoneus caboverdensis } \\
\text { Dworschak, Anker e Abed- } \\
\text { Navandi, } 2000\end{array}$ & $\begin{array}{l}\text { Neocallichirus pachydactylus (A. Milne- } \\
\text { Edwards, 1870) }\end{array}$ & Dworschak et al., 2000 \\
\hline Salmoneus degravei Anker, 2010 & Neocallichirus grandimana (Gibbes, 1850) & Anker, 2010 \\
\hline $\begin{array}{l}\text { Salmoneus durisi Anker et } \\
\text { Ashrafi, } 2019\end{array}$ & Neocallichirus calmani (Nobili, 1904) & Anker, Ashrafi, 2019 \\
\hline $\begin{array}{l}\text { Salmoneus ikaros Anker, Al- } \\
\text { Kandari et De Grave, } 2020\end{array}$ & Balsscallichirus masoomi (Tirmizi, 1970) & Anker et al., 2020 \\
\hline $\begin{array}{l}\text { Deioneus sandizelli Dworschak, } \\
\text { Anker et Abed-Navandi, } 2000\end{array}$ & $\begin{array}{l}\text { Corallianassa intesi (de Saint Laurent \& Le } \\
\text { Loeuff, 1979) and Neocallichirus } \\
\text { pachydactylus (A. Milne-Edwards, 1870) }\end{array}$ & Dworschak et al., 2000 \\
\hline \multicolumn{3}{|c|}{ Host unknown } \\
\hline Salmoneus poupini Anker, 2011 & $\begin{array}{l}\text { possibly, associated with a burrow of } \\
\text { Glypturus sp. (Callianassidae) }\end{array}$ & Anker, 2011 \\
\hline $\begin{array}{l}\text { Salmoneus singaporensis Anker, } \\
2003\end{array}$ & $\begin{array}{l}\text { possibly, associated with burrows of Alpheus } \\
\text { rapacida De Man, } 1908 \text { (Alpheidae) }\end{array}$ & $\begin{array}{c}\text { Johnson, 1962; Anker, } \\
\text { 2003; Anker, De Grave, } \\
2016\end{array}$ \\
\hline $\begin{array}{l}\text { Salmoneus tricristatus Banner, } \\
1959\end{array}$ & possibly, burrows of large Alpheus sp. & Anker et al., 2015 \\
\hline Salmoneus venustus Anker, 2019 & $\begin{array}{l}\text { possibly, associated with a burrow of } \\
\text { Glypturus sp. (Callianassidae) }\end{array}$ & Anker, 2019 \\
\hline
\end{tabular}

among Alpheidae known in association with upogebiid mudshrimps. Representatives of Athanas Leach, 1814, Betaeus Dana, 1852, Leptalpheus Williams, 1965, Leptathanas De Grave et Anker, 2008 and Stenalpheops Miya, 1997 are also known in associations with the upogebiid mudshrimps, mostly from the genus Upogebia Leach, 1814 (Table 2).

With the new species, the diversity of the genus Salmoneus in coastal waters of Vietnam now consists of 8 species. All other species, namely S. rostratus
Barnard, 1962, S. nhatrangensis Anker et Marin, 2006, S. auroculatus Anker et Marin, 2006, S. falcidactylus Anker et Marin, 2006, S. pusillus Anker et Marin, 2006, S. alpheophilus Anker et Marin, 2006 and S. venustus Anker, 2019 were recorded and described from Nha Trang Bay, central Vietnam [Anker, Marin, 2006; Anker, 2019]. This is, of course, potentially very far from the true diversity, and research will be continued, and there are more unknown species awaiting discovery. 
Table 2. Infaunal alpheid shrimps (Alpheidae) known from burrows of mudshrimps of the genus Upogebia Leach, 1814 (Gebiidea: Upogebiidae).

Таблица 2. Инфаунные креветки-альфеиды (Alpheidae), известные из нор роющих креветок рода Upogebia Leach, 1814 (Gebiidea: Upogebiidae).

\begin{tabular}{|c|c|c|}
\hline Associated species & Host & Reference \\
\hline $\begin{array}{l}\text { Athanas dentirostris Anker, Jeng et } \\
\text { Chan, } 2001\end{array}$ & $\begin{array}{l}\text { Upogebia aff. takaoensis Sakai } \\
\text { and Türkay, } 1995\end{array}$ & Anker et al., 2001 \\
\hline Betaeus levifrons Vinogradov, 1950 & Upogebia major (De Haan, 1841) & $\begin{array}{l}\text { Marin, 2010; Marin, } \\
\text { Antokhina, } 2020\end{array}$ \\
\hline $\begin{array}{l}\text { Betaeus longidactylus Lockington, } \\
1877\end{array}$ & $\begin{array}{l}\text { Upogebia pugettensis (Dana, } \\
\text { 1852) }\end{array}$ & $\begin{array}{l}\text { Hart, 1964; Campos et al., } \\
2009\end{array}$ \\
\hline Betaeus ensenadensis Glassell, 1938 & $\begin{array}{l}\text { Upogebia pugettensis (Dana, } \\
1852 \text { ) and U. macginiteorum } \\
\text { (Williams, 1986) }\end{array}$ & Campos et al., 2009 \\
\hline Betaeus harrimani Rathbun, 1904 & $\begin{array}{l}\text { Upogebia pugettensis (Dana, } \\
\text { 1852) }\end{array}$ & $\begin{array}{l}\text { Hart, 1964; Campos et al., } \\
2009\end{array}$ \\
\hline $\begin{array}{l}\text { Leptalpheus felderi Anker, Vera } \\
\text { Caripe et Lira, } 2006\end{array}$ & $\begin{array}{l}\text { Upogebia omissa Gomes Corrêa, } \\
1968\end{array}$ & Anker et al., 2006 \\
\hline Leptalpheus forceps Williams, 1965 & Upogebia affinis (Say, 1818) & $\begin{array}{l}\text { Williams, 1965; Saloman, } \\
1971\end{array}$ \\
\hline $\begin{array}{l}\text { Leptalpheus mexicanus Ríos et } \\
\text { Carvacho, } 1983\end{array}$ & $\begin{array}{l}\text { Upogebia dawsoni Williams, } \\
1986\end{array}$ & $\begin{array}{l}\text { Ríos, Carvacho, 1983; Ríos, } \\
\text { 1992; Campos et al., } 1995\end{array}$ \\
\hline $\begin{array}{l}\text { Leptathanas powelli De Grave et } \\
\text { Anker, } 2008\end{array}$ & $\begin{array}{l}\text { Upogebia furcata (Aurivillius, } \\
\text { 1898) }\end{array}$ & De Grave, Anker, 2008 \\
\hline Stenalpheops anacanthus Miya, 1997 & Upogebia major De Haan & Miya, 1997 \\
\hline Stenalpheops koreanus Kim, 1998 & $\begin{array}{l}\text { Upogebia edulis Ngoc-Ho et } \\
\text { Chan, } 1992 \text { and U. major De } \\
\text { Haan }\end{array}$ & $\begin{array}{c}\text { Miya, 1997; Hayashi 1998; } \\
\text { Kim, 1998; Anker et al., } \\
2001\end{array}$ \\
\hline
\end{tabular}

Acknowledgements. This study was supported by the Russian Foundation of Basic Researches (RFBR) with grant grants No. 18-04-01093_A and 20-04-00803_A. Author is deeply grateful to the co-directors of the Southern Department of the Russian-Vietnam Tropical Centre (Ho Chi Minh City, Vietnam) and Sergey Sinelnikov (A.N. Severtsov Institute of Ecology and Evolution of RAS, Moscow) for help during the field sampling. Dr. Tomoyuki Komai (Natural History Museum and Institute, Chiba, Japan) and Dr. Sammy De Grave (Oxford University Museum of Natural History, GB) have kindly reviewed and greatly improved the manuscript.

\section{References}

Anker A. 2003. Alpheid shrimps from the mangroves and mudflats of Singapore. Part I. Genera Salmoneus, Athanas and Potamalpheops, with the description of two new species (Crustacea: Decapoda: Caridea) // Raffles Bulletin of Zoology. Vol.51. No.2. P.283-314.

Anker A. 2007. New species and records of alpheid shrimps, genera Salmoneus Holthuis and Parabetaeus Coutiere, from the tropical western Atlantic (Decapoda, Caridea) // Zootaxa. Vol.1653. P.21-39. https://doi.org/10.11646/zootaxa.1653.1.2

Anker A. 2010. The shrimp genus Salmoneus Holthuis, 1955 (Crustacea, Decapoda, Alpheidae) in the tropical western Atlantic, with description of five new species // Zootaxa. Vol.2372. P.177-205. https://doi.org/10.11646/zootaxa.2372.1.18

Anker A. 2011. Three new species of the alpheid shrimp genus Salmoneus Holthuis, 1955 (Crustacea, Decapoda) from the tropical western Pacific // Zootaxa. Vol.2839. No.1. P.67-84. https://doi.org/10.11646/zootaxa.2839.1.3
Anker A. 2019. On three symbiotic species of the alpheid shrimp genus Salmoneus Holthuis, 1955 from the Indo-West Pacific, including one new to science (Malacostraca: Decapoda: Caridea) // Zootaxa. Vol.4651. No.1. P.51-63. https://doi.org/10. 11646/zootaxa.4651.1.3

Anker A., Ashfari H. 2019. Salmoneus durisi sp. nov., an infaunal alpheid shrimp probably associated with callianassid ghost shrimps in the tropical Indo-West Pacific (Malacostraca: Decapoda: Caridea) // Zootaxa. Vol.4651. No.1. P.64-74. https:// doi.org/10.11646/zootaxa.4651.1.4

Anker A., De Grave S. 2016. An updated and annotated checklist of marine and brackish caridean shrimps of Singapore (Crustacea, Decapoda) // Raffles Bulletin of Zoology. Suppl. No.34. P.343-454.

Anker A., Lazarus J.F. 2015. On two new species of the shrimp genus Salmoneus Holthuis, 1955 (Decapoda, Caridea, Alpheidae) from the tropical eastern Pacific // Zootaxa. Vol.3957. No.5. P.520-534. https://doi.org/10.11646/zootaxa.3957.5.2

Anker A., Marin I.N. 2006. New records and species of Alpheidae (Crustacea, Decapoda) from Vietnam. Part I. Genus Salmoneus Holthuis, 1955 // Raffles Bulletin of Zoology. Vol.54. P.295-319.

Anker A., Jeng M.-S., Chan T.-Y. 2001. Two unusual species of Alpheidae (Decapoda: Caridea) associated with upogebiid mudshrimps in the mudflats of Taiwan and Vietnam // Journal of Crustacean Biology. Vol.21. No.4. P.1049-1061. https://doi. org $/ 10.1163 / 20021975-99990197$

Anker A., Vera Caripe J.A., Lira C. 2006. Description of a new species of commensal alpheid shrimp (Crustacea, Decapoda) from the southern Caribbean Sea // Zoosystema. Vol.28. No.3. P.683-702.

Anker A., Firdaus M., Pratama I.S. 2014. Salmoneus yoyo nov. sp., a peculiar new infaunal shrimp from Lombok, Indonesia (Decapoda, Caridea, Alpheidae) // Zootaxa. Vol.3852. No.4. P.489- 
495. https://doi.org/10.11646/zootaxa.3852.4.6

Anker A., Pratama I.S., Firdaus M., Rahayu D.L. 2015. On some interesting marine decapod crustaceans (Alpheidae, Laomediidae, Strahlaxiidae) from Lombok, Indonesia // Zootaxa. Vol.3911. No.3. P.301-42. https://doi.org/10.11646/zootaxa. 3911.3.1

Anker A., Al-Kandari M., De Grave S. 2020. On two species of the alpheid shrimp genus Salmoneus Holthuis, 1955 from Kuwait, one of them new to science (Malacostraca: Decapoda: Caridea) // Zootaxa. Vol.4780. No.1. P.77-92. https://doi.org/10.11646/ zootaxa.4780.1.3

Ashelby C.W., De Grave S., Van Xuân N. 2018. A new species of Palaemon from C?n Gi? District, Vietnam, previously confused with Palaemon sewelli (Kemp, 1925) // Crustacean Research. Vol.47. P.17-27. https://doi.org/10.18353/crustacea.47.0_17

Avise J.C. 1993. Perspective: The evolutionary biology of aging, sexual reproduction, and DNA repair // Evolution. Vol.47. No.5. P.1293-1301. https://doi.org/10.1111/j.1558-5646.1993. tb02155.x

Campos E., De Campos A.R., Manriquez I. 2009. Intertidal thalassinidean shrimps (Thalassinidea, Callianassidae and Upogebiidae) of the west coast of Baja California, Mexico: Annotated checklist, key for identification, and symbionts // Crustaceana. Vol.82. P.1249-1263. https://doi.org/10.1163/ 001121609 X12481627024454.

Campos E., Felix Pico E.F., Garcia Dominguez F. 1995. Distribution and host records for four symbiotic crustaceans of the Mexican Paci?c (Stomatopoda and Decapoda) // Bulletin of Southern California Academy of Sciences. Vol.94. No.2. P.176178 .

Chertoprud E.S., Spiridonov V.A., Marin I.N., Mokievsky V.O. 2012. Brachyuran crabs (Crustacea Decapoda Brachyura) of the mangrove intertidal zone of southern Vietnam. In: Britayev T.A., Pavlov D.S. (eds.). Benthic fauna of the Bay of Nhatrang, Southern Vietnam. Vol.2. Moscow: KMK Scientific Press. P.258-295.

Costa-Böddeker S., Thuyên L.X., Schwarz A., Hoàng H.D., Schwalb A. 2016. Diatom assemblages in surface sediments along nutrient and salinity gradients of Thi Vai estuary and Can Gio mangrove forest, Southern Vietnam // Estuaries and Coasts. https://doi.org/10.1007/s12237-016-0170-5

Cunha A.M., Terossi M., Mantelatto F.M., Almeida A.O. 2020. Delimiting the snapping shrimp Alpheus lobidens De Haan, 1849 (Caridea: Alpheidae) based on morphological and molecular data // Zootaxa. Vol.4718. No.3. P.337-354. https://doi.org/ 10.11646/zootaxa.4718.3.3

David F., Marchand C., Nguyen T.-N., Van V.T., Taillardat P., Meziane T. 2019. Trophic relationships and basal resource utilisation in the Can Gio Mangrove Biosphere Reserve (Southern Vietnam) // Journal of Sea Research. Vol.145. P.35-43. https://doi.org/10.1016/j.seares.2018.12.006

David F., Marchand C., Taillardat P., Nguyen T.-N., Meziane T. 2018. Nutritional composition of suspended particulate matter in a tropical mangrove creek during a tidal cycle (Can Gio, Vietnam) // Estuarine, Coastal and Shelf Science. Vol.200. 126e130. https://doi.org/10.1016/j.ecss.2017.10.017

De Grave S. 2004. A new species of Salmoneus (Crustacea: Decapoda: Alpheidae) from Palau. Bulletin de l'Institut Royal des Sciences Naturelles de Belgique // Bulletin van het Koninklijk Belgisch Instituut voor Natuurwetenschappen. Vol.74. P.41-48.

De Grave S., Anker A. 2008. Leptathanas powelli, gen. nov., sp. nov., a new infaunal alpheid shrimp associated with upogebiid mudshrimps in Nigeria (Crustacea Decapoda) // Zootaxa Vol.1750. P.43-52. http://doi.org/10.11646/zootaxa.1750.1.4

De Grave S., Fransen C.H.J.M. 2011. Carideorum catalogus: the recent species of the dendrobranchiate, stenopodidean, procarididean and caridean shrimps (Crustacea: Decapoda) // Zoologische Mededelingen. Vol.85. No.9. P.195-589.

De Grave S., Wilkins H.K.A. 1997. A new record of Salmoneus rostratus Barnard, 1962 (Decapoda, Alpheidae) from Hansa Bay, Papua New Guinea // Crustaceana. Vol.70. No.5. P.633636.
De Grave S., Park J.-H., Anker A. 2020. A redescription of Salmoneus tafaongae Banner \& Banner, 1966 (Malacostraca: Decapoda: Alpheidae) // Crustacean Research. Vol.49. P.173-186. http://doi.org/10.18353/crustacea.49.0_173

Diele K., Tran Ngoc D.M., Geist S.J., Meyer F.W., Pham Q.H., Saint-Paul U., Tran T., Berger U. 2013. Impact of typhoon disturbance on the diversity of key ecosystem engineers in a monoculture mangrove forest plantation, Can Gio Biosphere Reserve, Vietnam // Global and Planetary Change. Vol.110(B). P.236-248.

Ïuriš Z. Horká I. 2016. Salmoneus chadwickae, a new alpheid shrimp (Crustacea: Decapoda: Alpheidae) from the Red Sea, with remarks on related or regional congeners // Marine Biodiversity. Vol.46. No.4. P.773-793. https://doi.org/10.1007/ s12526-015-0427-4

Dworschak P.C., Anker A., Abed-Navandi D. 2000. A new genus and three new species of alpheids (Decapoda: Caridea) associated with thalassinids // Annalen des Naturhistorischen Museums in Wien. Vol.102B. P.301-320.

FAO 1993. Mangrove for production and protection. A changing Resource System: Case Study in Can Gio District, South Vietnam. Field Document No.43. Bangkok: Food and Agriculture Organization of the United Nations.

FAO 2007. The world's mangroves 1980-2005. FAO Forestry Paper 153. Rome: Food and Agriculture Organization of the United Nations.

Felder D.L., Manning R.B. 1986. A new genus and two new species of alpheid shrimps (Decapoda: Caridea) from south Florida // Journal of Crustacean Biology. Vol.6. P.497-508. https:// doi.org/10.2307/1548189

Fransen C.H.J.M. 1991. Salmoneus sketi, a new species of alpheid shrimp (Crustacea: Decapoda: Caridea) from a submarine cave in the Adriatic // Zoologische Mededelingen. Vol.65. P.171179.

Gillikin D.P., De Grave S., Tack J.F. 2001. The occurrence of the semi-terrestrial shrimp Merguia oligodon (De Man, 1888) in Neosarmatium smithi H. Milne Edwards, 1853 burrows in Kenyan mangroves // Crustaceana. Vol.74. No.5. P.505-507. https://doi.org/10.1163/156854001750243081

Hart J.F.L. 1964. Shrimps of the genus Betaeus on the Pacific coast of North America with descriptions of three new species // Proceedings of the United States National Museum. Vol.115. P.431-466. https://doi.org/10.5479/si.00963801.115-3490.431

Hayashi K.I. 1998. A new genus and a new species of alpheid shrimp (Decapoda, Caridea) from Japan // Zoosystema. Vol.20. No.2. P.229-238

Hossain M.D., Nuruddin A.A. 2016. Soil and Mangrove: A Review // Journal of Environmental Science and Technology. Vol.9. No.2. P.198-207. https://doi.org/10.3923/jest.2016.198.207

Johnson D.S. 1962. A synopsis of the Decapoda Caridea and Stenopodidea of Singapore, with notes on their distribution and a key to the genera of Caridea occurring in Malaysian waters // Bulletin of the National Museum Singapore. Vol.30. P.44-79.

Ng P.K.L., Kang N. 1988. The mud lobster Thalassina // Nature Malaysiana. Vol.13. No.4. P.28-31.

Kessing B., Croom H., Martin A., McIntosh C., Mc Millan W.O., Palumbi S. 1989. The simple fool's guide to PCR, version 1.0. Department of Zoology, University of Hawaii, Honolulu.

Kim W. 1998. Chelomalpheus koreanus, a new genus and species of snapping shrimp from Korea (Crustacea: Decapoda: Alpheidae) // Proceedings of the Biological Society of Washington. Vol.111. No.1. P.140-145.

Knowlton N., Weigt L.A., Solórzano L.A., Mills D.K., Bermingham E. 1993. Divergence in proteins, mitochondrial DNA, and reproductive compatibility across the Isthmus of Panama // Science. Vol.260. P.1629-1632. https://doi.org/10.1126/science. 8503007

Komai T. 2009. A new species of the alpheid shrimp genus Salmoneus (Decapoda, Caridea) from the Ryukyu Islands, Japan, associated with a callianassid ghost shrimp (Decapoda, Thalassinidea) // Crustaceana. Vol.82. P.869-880. https://doi. org/10.1163/156854009X427405 
Komai T., Anker A. 2012. A distinctive new species of the alpheid genus Salmoneus Holthuis, 1955 (Crustacea: Decapoda: Caridea) from the northwestern Pacific // Zootaxa. Vol.3344. P.6068. https://doi.org/10.11646/zootaxa.3344.1.4

Komai T., Maenosono T., Naruse T. 2021. A new species of alpheid shrimp tentatively assigned to Salmoneus Holthuis, 1955 (Decapoda: Caridea) from the Ryukyu Islands, Japan // Zootaxa. Vol.4920. No.2. P.287-296. https://doi.org/10.11646/zootaxa.4920.2.9

Komai T., Yamada Y., Yunokawa K. 2015. A new cave-dwelling species of the alpheid shrimp genus Salmoneus Holthuis, 1955 (Crustacea: Decapoda: Caridea) from the Ryukyu Islands, southern Japan // Zootaxa. Vol.4028. No.3. P.413-420. https:// doi.org/10.11646/zootaxa.4028.3.6

Kuenzer C., Vo T.Q. 2013. Assessing the Ecosystem Services Value of Can Gio Mangrove Biosphere Reserve: Combining Earth-Observation- and Household-Survey-based Analyses // Applied Geography. Vol.45. P.167-184. https://doi.org/10. 1016/j.apgeog.2013.08.012

Marin I. 2010. Redescription of the alpheid shrimp Betaeus levifrons Vinogradov, 1950 (Crustacea, Decapoda, Alpheidae) from Peter the Great Bay, Russian coast of the Sea of Japan Zootaxa. Vol.2613. P.51-60. https://doi.org/10.11646/zootaxa.2613.1.5

Marin I. 2021. A new species of the genus Potamalpheops (Crustacea: Decapoda: Alpheidae) from the intertidal mangrove swamps of South Vietnam // Arthropoda Selecta. Vol.30. No.2. P.179191.

Marin I., Antokhina T. 2020. Hidden burrow associates: macrosymbiotic assemblages of subtidal deep-burrowing invertebrates in the northern part of the Sea of Japan // Marine Biodiversity. Vol.50. No.4. P.1-22. https://doi.org/10.1007/ s12526-020-01065-9

Miya Y. 1997. Stenalpheops anacanthus, new genus, new species (Crustacea, Decapoda, Alpheidae) from the Seto Inland Sea and the Sea of Ariake, south Japan // Bulletin of the Faculty of Liberal Arts, Natural Science, Nagasaki University. Vol.38. P.145-161.

Moberg F., Rönnbäck P. 2003. Ecosystem services of the tropical seascape: interactions, substitutions and restoration. Ocean Coast // Manage. Vol.46. P.27-46.

Ng P.K.L., Sivasothi N. 2002. A guide to the mangroves of Singapore 1: The ecosystem and plant diversity. Singapore: Singapore Science Centre. $160 \mathrm{pp}$.

Oliveira M.V., Costa-Souza A.C., Guimarães F.J., Almeida A.O. 2015. Observations on the life history of a rare shrimp, Salmoneus carvachoi (Crustacea: Caridea: Alpheidae), a possible simultaneous hermaphrodite // Marine Biodiversity Records. Vol.8. e141. https://doi.org/10.1017/S1755267215001219

Pham T.-L. 2017. Environmental Gradients Regulate the Spatiotemporal Variability of Phytoplankton Assemblages in the Can Gio Mangrove Biosphere Reserve, Vietnam // Ocean Science Journal. Vol.52. P.537-547. http://doi.org/10.1007/s12601-0170045-0

Ríos R. 1992. Camarónes carideos del Golfo de California. VI. Alpheidae del estuario de Mulegé y de Bahía Concepción, Baja California Sur, México (Crustacea: Caridea) // Proceedings of San Diego Society of Natural History. Vol.14. P.1-13.

Ríos R, Carvacho A. 1983. Caridean shrimps of the Gulf of California. III. Leptalpheus mexicanus, new species (Crustacea, Decapoda, Alpheidae) // Journal of Crustacean Biology. Vol.3. P.306-313.

Saloman C.H. 1971. The shrimp Leptalpheus forceps in Old Tampa Bay, Florida // Quarterly Journal of the Florida Academy of Science. Vol.34. No.1. P.67-77.

Shih H.-T., Hsu J.-W., Wong K.J.H., Ng N.K. 2019. Review of the mudflat varunid crab genus Metaplax (Crustacea, Brachyura, Varunidae) from East Asia and northern Vietnam // ZooKeys. Vol.877 P.1-29. http://doi.org/10.3897/zookeys.877.38300

Valiela I., Bowen J.L., York J.K. 2001. Mangrove forests: one of the World's threatened major tropical environments // BioScience. Vol.51. P.807-815.

Van Xuân N. 1992. Review of Palaemoninae (Crustacea: Decapoda: Caridea) from Vietnam, Macrobrachium excepted // Zoologische Mededelingen. Vol.66. No.2. P.19-47.

Van Xuân N. 2001. A new alpheid shrimp (Crustacea: Decapoda: Alpheidae) from South Vietnam // Zoologische Mededelingen. Vol.75. No.1-15. P.217-228.

Vinh T.V., Allenbach M., Linh K.T.V., Marchand C. 2020. Changes in Leaf Litter Quality During Its Decomposition in a Tropical Planted Mangrove Forest (Can Gio, Vietnam) // Frontiers of Environmental Science \& Engineering. Vol.8. P.10. https:// doi.org/10.3389/fenvs.2020.00010

Walters B.B., Rönnbäck P., Kovacs J.M., Crona B., Hussain S.A., Badola R., Primavera J.H., Barbier E., Dahdouh-Guebas F. 2008. Ethnobiology, socio-economics and management of mangrove forests: a review // Aquatic Botany. Vol.89. P.220-236, http://doi.org/10.1016/j.aquabot.2008.02.009

Williams A.B. 1965. A new genus and species of snapping shrimp (Decapoda, Alpheidae) from the southeastern United States // Crustaceana. Vol.9. P.192-198. https://doi.org/10.1163/ $156854065 \times 00352$

Responsible editor K.G. Mikhailov 